\title{
EDUCATING KNOWLEDGE MANAGEMENT PROFESSIONALS \\ IN THE ERA OF KNOWLEDGE ECONOMY
}

\author{
Hsueh-hua Chen \\ sherry@ccms.ntu.edu.tw \\ Personal Homepage: http://www.lis.ntu.edu.tw/ sherry/ \\ Tzu-heng Chiu \\ tzchiu@mail.lis.ntu.edu.tw \\ Personal Homepage: http://www.abin.com.tw/ tzchiu/
}

$\&$

Jung-Wei Fan

Undergraduate Student

Department of Library and Information Science

National Taiwan University

\section{TAIWAN}

Prof. Dr. Hsueh-hua Chen has served as the Director of the Department of Research \& Development, National Open University in Taipei, Taiwan prior joining the National University of Taiwan as its Associate Professor in 1988. She is currently the Chairman of the Department of Library and Information Science. She has conducted quite an extensive research on Metadata and has published more than fifty journal articles, conference papers, books and technical reports.

Tzu-heng Chiu is an Instructor at the Department of Library and Information Science, Fu-Jen Catholic University, Taipei, Taiwan and is currently pursuing a Ph.D. programme at the National Taiwan University. Before joining the department, Tzu-heng Chiu was a library practitioner at the Lee-Ming Institute of Technology, Taipei from 1996-1997 and at the National Taiwan University, Taipei from 1998-1999. Tzu-heng Chiu has published many articles which are mostly in Chinese 


\section{ABSTRACT}

The era of knowledge economy has come, and "knowledge" has become a key resource for enterprises. How to keep creating and utilizing new knowledge has become an important topic for modern business administration. In the future, how to manage "knowledge" efficiently and effectively will be a crucial issue. However, due to differences in training backgrounds, people may have different perspectives on knowledge management; and effectiveness of knowledge management may not be maximized due to lack of integration. Because of this, the Departments of Library \& Information Science, Business Administration, Information Management, and Computer Science \& Information Engineering in National Taiwan University have worked together to propose a "Knowledge Management Curriculum Program" with an aim to educate and train allround knowledge management professionals. This paper begins with that knowledge management $(\mathrm{KM})$ will be the trend of business administration in the 21 st century, followed by the need to train cross-disciplinary KM professionals and channels for such training. Lastly, it takes "KM Curriculum Program, NTU" as an example to explain the ideas behind its education and training. Furthermore, by sharing of experiences, it is our hope to motivate other colleges and universities to draw up similar programs to train skillful KM professionals and to improve Taiwan's competitiveness in the business world. go to top

\section{INTRODUCTION}

The evolution of information network and information technology has changed our daily life and production pattern. As a result, information and knowledge become the crucial factors which affecting the economic development of every country. In 1996, the "Report of Knowledge Economics" published by OECD Organization for Economic Co-operation and Development advocated that knowledge-based economy will change patterns of the worldwide economic development, and knowledge will be a key capital to improve the production and economic growth. Furthermore, when knowledge and IT joint together, knowledge-intensive industries will be the major business all over the world. (Council for Economics Planning and Development, 2000) Since then, "knowledge economy" has become a highly valued concept for scholars and governments. The R.O.C. government also realized the importance of this issue, Council for Economic Planning and Development, Executive Yuan held the "Conference of Develop Knowledge-based Economy in Taiwan" during 4th-5th November 2000, and industry leaders, scholars, people's representatives, and government officers were invited. (Conference of Develop .., 2000)

The era of knowledge economy has come, and knowledge has become a key resource for enterprises. How to keep creating and utilizing new knowledge has become an important topic for modern business administration. In other words, if a corporate can manage the tacit knowledge embedded in employees' experiences and business operating process, and the explicit knowledge scattered within and outside the organization successfully, its competitiveness would be greatly improved. Therefore, replacing the concepts of TQM, BPR, and learning organization, "knowledge management" has become the focus of business management. (Village, 2000) However, knowledge resources are quite different from traditional capitals such as land, money, equipment, etc. Many enterprises now are still unfamiliar with this resource. In the future, how to manage knowledge resources effectively will become a hot research topic.

However, due to the difference in education backgrounds, people may have different perspectives on knowledge management; and effectiveness of knowledge management may not be maximized due to lack of integration. Because of this, the Departments of Library \& 
Information Science, Business Administration, Information Management, and Computer Science \& Information Engineering in National Taiwan University have worked together to propose a "Knowledge Management Curriculum Program" with an aim to educate and train all-round knowledge management professionals. This paper begins with that knowledge management $(\mathrm{KM})$ will be the trend of business administration in the 21st century, followed by the need to train crossfield KM professionals and channels for such training. Lastly, it takes "KM Curriculum Program, NTU" as an example to explain the ideas behind its education and training. By sharing of experiences, we hope to motivate other colleges and universities to draw up similar programs to train skillful KM professionals and to improve Taiwan's competitiveness in the business world. go to top

\section{KM WILL BE THE TREND OF BUSINESS ADMINISTRATION IN THE 21ST CENTURY}

Business world now recognizes the importance of knowledge management, and knowledge is viewed as a major competitive capital. Consulting firms such as Arthur Andersen, Andersen Consulting, Booz Allen \& Hamilton, Price Waterhouse, the Gartner Group, KPMG Pear Marwick, and Coopers \& Lybrand know that KM will be the trend in the 21st century, so all of them are involving in KM. (Srikantaiah, 2000)

Furthermore, famous computer, telecommunication and system companies are investing in the research and development of KM infrastructure and applications. Nowadays, there are many mature KM related IT products in the market, and some IT companies even provide overall KM solution service. Microsoft, the leader of computer application software, entered this market in May 1999. Bill Gates not only promoted KM concept in his book "Business@The Speed of Thought: using a digital nervous system", his company also announced a platform-wide KM initiative. Moreover, the company launched a portal-like product "Digital Dashboard", attempting to be the front end for other KM-related components. ("The KM year..." , 2000) IBM, another big player in the IT industry, merged the Lotus (note: Lotus Notes is a popular intranet application) and began to coordinate their approaches to KM in 1999. The focus of its Global Services Consulting Group is now on the KM service. ("The KM year...", 2000) These two examples demonstrate IT industry's concern on KM market. Enterprises therefore have more choices for $\mathrm{KM}$-related IT products, and can implement KM projects easier now. As a result, organizations with a farsighted view can apply KM into organization process to enhance collaborations, to eliminate information overload, to enhance teamwork, to improve productivity, and enable innovation. (Srikantaiah, 2000)

In addition to the business world, professional organizations also have noticed the importance of KM. American Productivity and Quality Center (APQC), American Society for Information Science and Technology (ASIST), and Special Library Association (SLA) are very concerned in KMrelated issues. (Srikantaiah, 2000)

In order to update the knowledge of their members, these organizations post relevant information in their newsletter and web site, hold many related conferences and workshops, and even provide consulting service. ASIST (http://www.asis.org), for example, chose related topics for its annual meeting - "Knowledge, creation, organization, and use" in 1999 and "Knowledge Innovations: celebrating our heritage, designing our future" in 2000. 9 Besides, the OCLC Institute (http://www.oclc.org/institute), the training institution of Online Computer Library Center, Inc., held several KM workshops in United States, Canada, and Asia (China, Hong Kong, Taiwan, etc.), to promote KM concepts and practices. go to top

\section{KM PROFESSIONALS NEED CROSS-DISCIPLINARY TRAINING}


In the field of KM research, some people define knowledge as an "object" (known as IT-track), others define it as a "process" (known as people-track). People can also approach this issue from either the organization or the individual level, and this $2 \times 2$ grid is shown in Table 1. Researchers and practitioners in IT-track usually have their education in computer or information science and their specialty is information management. Therefore, they advocate business process reengineering in the organizational level and develop an artificial intelligent system in the individual level. However, researchers and practitioners in people-track usually have education background in philosophy, psychology, sociology, or business management and their specialty is human resources management. Therefore, they emphasize organization theories in the organizational level, and tend to facilitate knowledge sharing in the individual level. ("What is...", 1999)

\section{Table 1}

Research Approaches of KM

\begin{tabular}{|c|c|c|}
\hline Track & $\begin{array}{c}\text { IT-track } \\
\text { Level }\end{array}$ & $\begin{array}{c}\text { People-track } \\
\text { Knowledge }=\text { Process }\end{array}$ \\
\hline Organization Level & Re-engineers & Organization theorists \\
\hline Individual Level & AI-specialists & Psychologists \\
\hline
\end{tabular}

Source What is Knowledge Management 〈http:/www.sveiby.com.au/KnowledgeManagement.html> Retrieved in Oct. 28. 2000

The above paragraph explains the importance of "management science"(especially the human resources management and organizational theory) and "information technology" to KM. This is the reason that when enterprises plan to implement a KM project, managers with business or IT background are usually assigned to be the project leader. However, after the KM system and reward system are set up, and people begin to share their knowledge, the top management then finds out this project team doesn't have the skill to organize knowledge systematically and to retrieve the knowledge effectively. At this point, top management realizes the information content management specialist, such as librarians or LIS professionals is essential.

Library and Information Science has been working on the acquisition, organization, storage, and dissemination of people's recorded knowledge for a long time. LIS professionals are specialized in managing information and knowledge. Consequently, we pay close attention to the development and education of KM. Recently, LIS schools in western world are expanding their curriculum, helping their graduates not only to work in the traditional library settings, but also to serve in the business world, becoming a member of the KM team. Among them, UC Berkeley, University of Michigan, University of North Carolina, and University of Maryland are the most famous ones.

However, since KM is a cross-disciplinary concept, people with mono education background are unable to maximize the function of KM. According to Davenport (2000), three domains which have interested in this area are: 1).Library and Information Science (referred as KM1), 2).Process engineering (referred as KM2), and 3). Organization theory (referred as KM3). Each of these domains has its focal points, and they can be summarized as follows:

- KM1: People with LIS education background represent this domain. They believe that KM is simply a new name for information management. They approach KM from the viewpoint of "knowledge organization", and advocate that knowledge workers need "intermediaries 
", such as LIS professionals, to support their work by organizing and managing appropriate information and knowledge. However, the biggest problem of this domain is that many librarians lacks knowledge on how business is perceived and created. As a result, they are unable to integrate their skills with the business objective to provide valueadded services. Therefore, the strategy of this domain is to recognize that although information management is important to $\mathrm{KM}$, it is only a part of $\mathrm{KM}$. LIS professionals should understand the whole picture of $\mathrm{KM}$, and then to utilize their information management skills in the KM environment.

- KM2: This domain can be divided into KM2.1 and KM2.2. People with the background of business process engineering represent KM2.1. They believe that $\mathrm{KM}$ is the management of "know-how". They are very system-oriented and emphasize in anatomizing and recompiling the existing process to discover and extract values. However, the biggest problem of KM2.1 is that process engineering people only focus on the "process", ignoring the tacit knowledge such as employees' competencies, skills, talents, thoughts, ideas, intuitions, commitments, motivations, and imaginations. KM2.2, on the other hand, recognizes that valuable insights and links across processes and resources are made by humans. Therefore, tools like "enterprise ontology" or "knowledge asset roadmap" are proposed.

- KM3: This domain believes that KM is the interplay of tacit and explicit knowledge, and the major job of knowledge manager is to convert human capital into structural capital. Davenport therefore concluded that $\mathrm{KM} 3$ is the best framework for $\mathrm{KM}$.

These different perspectives are due to different education backgrounds. And we believe that KM1 (knowledge organization), KM2 (process engineering) and KM3 (organization theory) should complement, rather than exclude one another, because all of them represent different facets of $\mathrm{KM}$. To implement a KM project, we must have professional skills from various disciplines, therefore, an interdisciplinary KM team is needed. Therefore, Wiig (1995) suggested that an ideal $\mathrm{KM}$ team should include information professionals, technology specialists, management representatives, subject matter experts, business process experts, and contingency management specialists...etc. However, team members from different disciplines should have a basic understanding of other KM- related fields, so they can use the same language to communicate and achieve the goal of KM projects. We therefore propose a cross-disciplinary KM curriculum program, hoping the future KM professionals will be able to attain a holistic view of KM. go to top

\section{PLANNING THE KNOWLEDGE MANAGEMENT CURRICULUM PROGRAM IN NATIONAL TAIWAN UNIVERSITY}

The great efforts made to give impetus to "program education" recently in Taiwan have close relation with the trend of our educational reformation (Programs have not been maturely institutionalized in our conventional education). In a symposium on Taiwan's educational system reform, the advantages of implementing programs in higher education were concluded as follows: (Yang, 2000)

1. To avoid waste of resources: As departments are unnecessarily subdivided, it will result waste in the utilization of resources and faculty. For example, "Administrative Management Program" can be offered jointly by the Department of Management and the Department of Public Administration. Thus, courses can be integrated and resources can be used more efficiently.

2. To focus on both specialty as well as extensiveness: Students' career 
tracks are usually limited by their single background under the traditional department-oriented system. Once competence-oriented programs are implemented, students may take extensive as well as focused curriculum. Through this kind of interdisciplinary training, more qualified KM workers can be trained.

3. Flexibility in practice: A program can be a major/minor course of one department, or cross-department. And mostly, a student may start his program at any year, so it is quite flexible in practice.

4. Extension education may be carried out more easily: Along with its flexibility and competence-orientation, program education which confer substantial credits/formal certificate will surely encourage a backflow of the working people. Considering the importance of knowledge management, future demand for KM workers, and the advantages and the trend of program education, a "Knowledge Management Curriculum Program" proposed by the Department of Library and Information Science, National Taiwan University (NTU LIS) was then incubated.

In the planning phase of this program, NTU LIS contacted the chairpersons and professors of the Department of Business Administration (NTU BA), Department of Information Management (NTU IM), and Department of Computer Science \& Information Engineering (NTU CSIE), and several meetings were held to discuss the scheme and feasibility of this knowledge management program. Meanwhile, relevant information about knowledge management and program designing were being collected extensively. These literatures from periodicals, dissertations, proceedings, unpublished academic works, and websites are important references that provide both evidences and concepts in our discussion and research. Literature analysis focuses on five aspects:

1. Study KM papers to analyze what "skills" do KM workers really need? And how can these skills be cultivated effectively?

2. Review the addressed perspectives and empirical researches by experts from relevant fields to draw the essential disciplines for knowledge management, and how to achieve these qualifications.

3. Refer to the competency-requirements for an ideal KM worker set by

management consultant companies and actual recruitment to adjust the training in our knowledge management program.

4. Analyze relevant programs and courses that have been established or are presently under planning by other academies in Taiwan or abroad. On one hand we can grasp the favorable planning approaches, on the other hand we might discovery some problems about the objectives, perceptions, and even resourceallocation in our own planning process.

5. Collect information of other existing programs offered in National Taiwan University to draw on their experience of curriculum design, credit allocation, organization operating, and measures and regulations.

The first preparatory meeting for our KM program was held on June 14th, 2000, participated by nine professors including four department chairpersons from NTU LIS, NTU BA, NTU IM, and NTU CSIE. As consensus was reached in the first meeting, the second preparatory meeting took place on July 6th, 2000. Before this meeting, we made a "course list" of domestic / overseas college courses related to knowledge management. The courses were categorized into three domains: "Resource", "Management", and "System". Along with the list, similar courses (with the qualified teachers) that have been offered in National Taiwan University during the last five years were mapped accordingly. The goal of the second meeting is to select and determine the 
program's content and core courses from about sixty items on the list.

Participated professors contributed their expertise on the selection of mandatory courses and integration of overlapping courses. Professors with similar background discussed and exchanged their opinions, and the curriculum was finalized as follows:

\begin{tabular}{|c|c|c|c|c|}
\hline \multicolumn{2}{|c|}{ Phase } & Course & \begin{tabular}{|l|}
$\begin{array}{l}\text { Mandatory } \\
\text { or Selective }\end{array}$ \\
\end{tabular} & Credit \\
\hline \multicolumn{2}{|c|}{ Fundamental } & Introduction to Knowledge Management & M & 2 \\
\hline \multirow{15}{*}{ Advanced } & \multirow{4}{*}{$\begin{array}{l}\text { Resource } \\
\text { Domain }\end{array}$} & Knowledge Organization & $\mathrm{M}$ & 3 \\
\hline & & Indexing and Abstracting & $\mathrm{S}$ & 2 \\
\hline & & $\begin{array}{c}\text { Information Retrieval (from Library } \\
\text { Science approach) }\end{array}$ & S & 3 \\
\hline & & $\begin{array}{l}\text { Business Information Service (including } \\
\text { Industry \& Business Library) }\end{array}$ & $S$ & 3 \\
\hline & \multirow{5}{*}{$\begin{array}{l}\text { Management } \\
\text { Domain }\end{array}$} & $\begin{array}{c}\text { Organizational Behavior (including } \\
\text { Organizational Learning) }\end{array}$ & M & 3 \\
\hline & & Human Resources Management & S & 3 \\
\hline & & Decision Support System & S & 3 \\
\hline & & Project Management & S & 3 \\
\hline & & Knowledge Economy & S & 3 \\
\hline & \multirow{6}{*}{$\begin{array}{l}\text { System } \\
\text { Domain }\end{array}$} & Knowledge Management Systems & $\mathrm{M}$ & 3 \\
\hline & & $\begin{array}{c}\text { Advanced Knowledge Management } \\
\text { Systems }\end{array}$ & S & 3 \\
\hline & & Artificial Intelligence & $\mathrm{S}$ & 3 \\
\hline & & $\begin{array}{c}\text { Information Retrieval \& Extraction (from } \\
\text { Computer Science approach) }\end{array}$ & S & 3 \\
\hline & & Natural Language Processing & S & 3 \\
\hline & & Database Management & $\mathrm{S}$ & 3 \\
\hline \multicolumn{2}{|c|}{ Practical } & $\begin{array}{l}\text { Special Topics in Knowledge } \\
\text { Management }\end{array}$ & $\mathrm{M}$ & 2 \\
\hline
\end{tabular}

\section{Table 2}

An Overview of the NTU "Knowledge Management Program" Curriculum

Among them, the "Introduction to Knowledge Management" is an introductory course, and "Special Topics in Knowledge Management" is practical training; "Organizational Behavior", "Knowledge Organization", and "Knowledge Management Systems" are mandatory core courses for each domain.

As the curricular framework has been drawn up in the second meeting, the third meeting on September 13th, 2000 was intended to formulate the proposal of our KM program, which comprised the formal title of our program, proposing departments, name list of participating professors, objectives, criteria for application and evaluation, regulations on studying the program, and brief description of courses in each phase. For the applicants, this part is quite important since rules and regulations for the program have been clarified. The rules can be summarized as below: 
1. This Knowledge Management Curriculum Program consists of three phases: fundamental, advanced, and practical courses. The approved applicants are recommended to take the fundamental course "Introduction of Knowledge Management" first in order to build up an overview about KM.

2. Among the advanced courses, "Knowledge Organization" of the Resource Domain, "Organizational Behavior" of the Management Domain, and "Knowledge Management Systems" of the System Domain are their respective mandatory courses.

3. The practical training "Special Topics in Knowledge Management" is mandatory and it is better to take this course after the relevant courses have been finished.

4. Besides the five mandatory courses mentioned above, students should select advanced courses according to their needs and obtain more than 20 credits; thus eligible for the certification criterion. Students who have finished the requirements will be conferred a "Certificate of Knowledge Management Curriculum Program" from National Taiwan University.

Through three preparatory meetings participated by 3 colleges, 4 departments, and 12 professors, the "KM Curriculum Program, NTU" has been mapped out. The program was passed in the NTU's educational administration meeting in Dec. 2000 and was scheduled to recruit students in Sep. 2001. It is our hope that the program can provide students with interdisciplinary and multi-faceted training of knowledge management. go to top

\section{CONCLUSIONS}

As knowledge management gets more and more important, an urgent demand for human resources in this field can be reflected directly in the recruiting and training of KM workers. The concept of knowledge management was initially addressed by the field of business administration, thus they've been taken leading steps in various institutions and measures. Take personnel training for example, enterprises may call up the qualified and implement all kinds of onthe-job training instantly when they need experienced KM workers. Hence we might say that business administration is the first discipline to sense the manpower market of knowledge management.

The demand for knowledge management professionals not only extends from practical business administration to its corresponding educational field, but also catches the attention from other disciplines extensively, among which Information Technology and Library \& Information Science are two of the most significant ones. The former holds as information technology has predominated the most convenient media and tools of our knowledge territory, the latter in another way, originating from its disciplinary tradition of classifying and organizing knowledge and stimulated by innovations of the new era, has awakened to its academic responsibility and the necessity to progress with the time.

To sum up, we find that no matter in business circle or in academic circle, the most active promoters for KM worker training are mainly from Business Administration, Information Technology, and Library \& Information Science. In Taiwan, we're just stepping into this area, but teams in many developed countries have taken actions vigorously about three years ago or even much earlier. So, there are plenty of knowledge management books, research reports, and periodical literatures available in English, and their numbers are still increasing tremendously. In view of the interdisciplinary and versatile training for KM professionals, we designed the curriculum consisting of three domains: "Resource", "Management", and "System" and stipulated 
that students must take the core courses of each domain to establish essential concepts about knowledge management approached by different disciplines. It is our hope that other colleges and universities can draw up similar programs to educate skillful KM professionals, who will play the role of catalysts to improve Taiwan's competitiveness in the business world and other fields so to gain a "favorable terrain" (or winning edge) in the competitive era of knowledge economy. go to top

\section{REFERENCES}

Council for Economics Planning and Development, Executive Yuan, R.O.C. (2000) Planning of Develop Knowledge-based Economy in Taiwan. (Taipei: CEPD, approved by the 2696th Executive Yuan Conference in 2000/08/30). Retrieved 2000/11/18 from http://www.aproc.gov.tw/kbe/ newpage8.htm Conference of Develop Knowledge-based Economy in Taiwan (2000) Retrieved 2000/11/18 from http://www.aproc.gov.tw/kbe/link7-1.htm

Davenport, E. and Cronin. B. (2000) Knowledge Management: Semantic Drift of Conceptual Shift? Retrieved 2000/11/27 from http://www.alise.org /nondiscuss/conf00_DavenportCronin_paper.htm The KM Year in Review (1999) Knowledge Management Magazine. Retrieved 2000/11/01 from http://www.destinationcrm.com/km/ dcrm_km_article.asp?id=110 Srikantaiah, T. K. (2000) Knowledge Management: A Faceted Overview. Knowledge Management for the Information Professional. Medford, NJ: ASIS, 7-17.

Village, P. (2000) Skills for Knowledge Environment. Information Management Journal, 34(3): 3341.

What is Knowledge Management (1999) Retrieved 2000/10/28 from http://www.sveiby.com.au/KnowledgeManagement.html Wiig, K. (1995) Knowledge Management Methods: Practical Approaches to Managing Knowledge, Schema Press, 17.

Yang, En-Wei (1996) Issues About Educational System Reform in Taiwan (In Chinese). Education Reform Newsletter, 21: 30-31. Retrieved 2000/11/27 from http://www.sinica.edu.tw /info/edu-reform/farea8/j21/30.html go to top 